\title{
Editorial: Plato or Prozac?
}

The latest in psychotherapy appears to be philosophical counselling. I s this on the principle that where nothing can be shown to work, anything is as good as anything else? R eading Plato might also have incidental advantages not available to those who are treated with pills, behavioural therapy or non-directive counselling. (As well as curing you, it might make you think.) Or is it that psychotherapists have rediscovered the classical ideal of philosophy as therapy? Can we expect a resurgence of the ancient Stoic virtues or of ataraxia or even of Spinozistic rationality among the psychologically afflicted?

$L$ ater philosophers have not always provided such positive precedents. W ould it really be a good idea to give $\mathrm{K}$ ierkegaard to the obsessively religious, or $\mathrm{N}$ ietzsche to the paranoid, or the early W ittgenstein to those who have difficulty in coping with everyday normality? N or is it easy to see how Sartre would help couples sort out their relationships, or R ussell someone pathologically insensitive to the feelings of others.

On reflection, it might be better to keep the pills after all. 